\title{
The Effect of the Style of The Principal's Leadership Towards the Teachers' Performance Through Work Motivation at Vocational High Schools
}

\author{
Isti Setya Rini ${ }^{1}$, Ismi Dwi Astuti Nurhaeni ${ }^{2}$, Cicilia Dyah Sulistyanngrum Indrawati ${ }^{3}$
}

\section{ARTICLE INFO}

Article History:

Received 01.09.2018

Received in revised form

24.11.2018

Accepted

Av ailable online

01.01.2019

\begin{abstract}
The real implementation of the teachers' performance of vocational high school has not been optimal yet. The reason is the teachers' lack of pedag ogic and professional competence as educators. Besides, the teachers have lack of work motivation which is reflected on their performance. On the other hand, the style of the principal's leadership contributes to the teachers' work pattern at schools. This study aims to determine the effect of principals' leadership style on teacher performance through work motivation in vocational business and management in Surakarta. This study uses a quantitative method with Structural Equation Modeling Partial Least Square (SEM-PLS) analysis. The study sample was 158 teachers of business and management vocational schools throughout Surakarta, Indonesia. The results showed that 1) the leadership style of school principals had a positive and significant influence on teacher performance of 0.557 and a statistical $\mathrm{T}$ value of $13.128 \geq 1.96 ; 2$ ) the leadership sty le of the principal has a positive and significant influence on work motivation of 0.709 and a statistical $\mathrm{T}$ value of $20.097 \geq 1.96 ; 3$ ) work motivation has a positive and signific ant effect on teacher performance at 0.785 and a statistic al $T$ value of $26.518 \geq 1.96 ; 4$ ) Principal leadership style has a positive and indirecteffect on teacher performance through work motivation of 0.453 and a statistical $T$ value of $8.125 \geq 1.96$. Therefore, teachers need to improve their performance with high work motivation and encouragement or support from the principal.
\end{abstract}

C IJERE. All rights reserved

Keywords: ${ }^{1}$

The style of the principal's leadership, work motivation, the teachers' performance.

\section{INTRODUCTION}

The existing problems in education showing the teachers' potential to be creative as an effort to improve their performance does not always develop fairly and smoothly. This is caused by the effects coming from the teachers' internal and external factors. Mulyasa (2013) stated that the definition of the improvement of teachers' performance is to improve the teachers' performance through guidance and supervision carried out continuously. Besides, Hadis and Nurhayati (2010) stated that the decline of the quality of education in Indonesia in general and the quality of higher education specifically seen from the macro perspective can be caused by the poor national education system and low human resources.

One factor that influences teacher performance is how the principal's leadership style. Principal leadership is the most important determinant of school excellence (Wahab, Fuad, Ismail, \& Majid; 2014) (Supriadi and Yusof; 2015) (Yieng and Daud; 2017). Leadership style is a process in which there is an element of influence (Wahlstrom \& Louis, 2008). The existence of a leadership style will establish cooperation and the existence of a vision and mission to achieve common goals within the organization. The principal is the center of education leaders who have a policy to be able to lead a school to achieve a predetermined goal (Vivianti and Hadi, 2015). Leadership has a close relationship with the results of one's performance because the success of a principal as a leader in moving and influencing subordinates to achieve goals depends very much on the authority of the leader himself and how to create a good collaboration within each subordinate and leader itself. The leadership style of the principal in leading will have an impact on the teacher's performance and in terms of creating a conducive school environment. According to Sulistiyorini (2001), a leader in education has to have skills in influencing, motivating, guiding, directing, and moving others. The skills are related with effective and efficient implementation and development of education, teaching, and training to achieve the determined education and teaching goals. Thus, the style of the leadership has to be appropriate.

Furthermore, the teachers' motivation work affects the teachers' performance. Motivation will arise in the teachers if there is attention, suitability, trust and satisfaction given by the principal. Besides, communication between teachers and principal and teachers and teachers has to be smooth so that it can improve the teachers' performance (Firmaw ati, Yusrizal, \& Usman, 2017). According to Usman (2013), work

1.2.3. Universitas Negeri Sebelas Maret Surakarta, istisetyarini@student.uns.ac.id， orcid.org/0000-0001-5741-5635 
motivation is defined as desire or need that can make someone get motivated to work. If there is motivation to have high achievement, there will be high teachers' performance coming from internal and external factors. The principal has an important role as a motivator or motivator from outside the teacher to be more motivated to achieve (Demir, 2008). Implementation of a good leadership pattern from the principal, because teachers who have low achievement motivation will be followed by low performance.

\section{Situation of the Problem}

On the other hand, the previous researches showed that some teachers still had lack of motivation to improve their competence, lack of mastery of pedagogic competence in the learning process, and lack of mastery of professional competence without having the renewal of learning materials. Besides, senior teachers acknowledged that they had lack of IT mastery. In addition, the principal's leadership could not fully influence, move, develop, and empower the teachers to improve their work motivation and performance. There was also limitation of time to guide and help the teachers in creating syllabus and lesson plan.

\section{Aim of the Study}

Based on these problems, the aim of this article is to examine 1) the influence of the principal's leadership style on teacher performance; 2) the influence of the principal's leadership style on work motivation;3) w ork motivation on teacher performance; 4) the influence of the principal's leadership style on teacher performance through work motivation. This research was conducted at Surakarta Vocational Schools, especially Vocational High Schools in business and management expertise.

\section{METHOD}

The research used a correlational quantitative research approach with ex-post facto design. The type of analysis w as path analysis. The design model of the research put the style of the principal's leadership as an exogenous variable, the teachers' performance as an endogenous variable, and work motivation as a mediating variable. Sample is part of the numbers and characteristics of the population (Sugiyono, 2010: 389). The sampling technique used proportional random sampling technique by lottery. Proportional random sampling is the technique of taking proportions to obtain representative samples, taking subjects from each stratum or regionally balanced or comparable in each region (Arikunto, 2006: 127). The population in this study were 263 teachers while the sample were 158 teachers of vocational high schools of business and management in Surakarta.

\section{Data Analyses}

The instrument used in this research was questionnaire. The data analysis technique was Structural Equation Modeling (SEM) with the program of Warp Partial Least Square (PLS) 3.0.

Hy pothesis testing is carried out by analyzing the results of the SEM questionnaire with the program of WarpPLS 3.0. First, SEM-PLS is appropriate for this research model because it uses latent variables and has calculated measurement error. Second, SEM analysis can simultaneously simulate multiple dependence as in this research model. Third, component-based SEM (PLS) can estimate a fairly complex model with a small sample size. The use of SEM in data analysis allows researchers to examine the relationship between complex variables in order to obtain a comprehensive picture of the overall model.

PLS is a component-based approach for testing structural equation model or commonly called SEM. By using PLS, it is possible to model structural equation with relatively small sample sizes and does not require normal multivariate assumptions. According to Ghozali (2006), analysis on PLS is carried out in three stages:

\section{a. Outer model analysis}

Outer model analysis is carried out to ensure that the measurement is appropriate to be used as a measurement (valid and reliable). Outer model analysis can be seen from some indicators:1) Convergent validity, 2) Discriminant validity, 3) Composite Reliability.

\section{b. Inner model analysis}

Inner model analysis/structural model analysis is carried out to ensure that structural model is built robustly and accurately. Inner model evaluation can be seen from some indicators: 1) Determination Coefficient $\left(\mathrm{R}^{2}\right)$, 2) Predictive Relevance, 3) Goodness of Fit Index (GoF).

\section{c. Hypothesis Testing}


Hypothesis testing is carried out by looking at the probability value and the statistics. For the probability value, the $\mathrm{p}$ value with alpha $5 \%$ is less than 0.05 . The $\mathrm{t}$-table value for alpha $5 \%$ is 1.96 . So, the hypothesis acceptance criteria is $\mathrm{t}$-statistics $>\mathrm{t}$-table.

This research was designed to determine the effect between an exogenous variable of the style of the principal's leadership, a mediating variable of work motivation, and an endogenous variable of the teachers' performance. The effect constellation between exogenous variable and endogenous variable can be seen in the following picture:

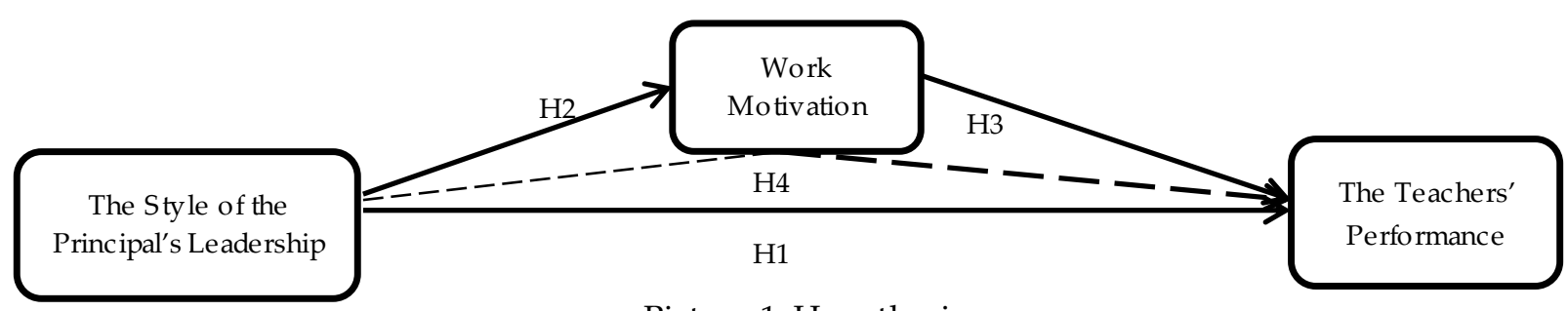

Picture 1. Hypothesis

Note:

$\longrightarrow=$ Direct effect

$-\mathbf{-} \rightarrow=$ Indirect effect

H1: There is an effect of the style of the principal's leadership towards the teachers' performance at vocational high schools in Surakarta.

$\mathrm{H} 2$ : There is an effect of the style of the principal's leadership towards work motivation at vocational high schools in Surakarta.

H3: There is an effect of work motivation tow ards the teachers' performance at vocational high schools in Surakarta.

H4: There is an effect of the style of the principal's leadership towards the teachers' performance through work motivation at vocational high schools in Surakarta.

\section{FINDINGS}

Based on the results of data processing using the WarpPLS 3.0 application, namely testing the inner model or structural model to see the relationship between the construct, significance value and R-square of the research model, the structural model was evaluated using the R-square for the dependent construct of $t$ test and the significance of the coefficient structural path parameters as follows:

\section{Outer model analysis}

\section{a. Convergent Validity}

Test parameters of convergent validity in the PLS measurement model with reflexive indicators can be measured based on loading factor with rule of thumb $>0.7$. The loading factor value with a rule of thumb between 0.5 - 0.6 can still be used (Yamin \& Kurniaw an, 2011: 202; Haryono, 2017: 405) or using AVE and Communality $>0.5$ parameters or using T-Statistics $\geq 1.96$ and P Value $\leq 0.05$. The results of the correlation between indicators and their constructs are show $n$ in the output below:

Table 1. Convergent Validity

\begin{tabular}{|c|c|c|c|c|}
\hline & $\begin{array}{c}\text { Original } \\
\text { Sample }\end{array}$ & Sample Mean & $\begin{array}{c}\text { Standard } \\
\text { Deviation }\end{array}$ & $\begin{array}{c}\mathrm{T} \\
\text { Statistics }\end{array}$ \\
\hline KG1 & 0.706 & 0.402 & 0.077 & 5.274 \\
\hline KG2 & 0.778 & 0.568 & 0.061 & 9.553 \\
\hline KG3 & 0.811 & 0.703 & 0.051 & 13.969 \\
\hline KG4 & 0.837 & 0.632 & 0.056 & 11.455 \\
\hline KG5 & 0.812 & 0.704 & 0.052 & 13.776 \\
\hline KG6 & 0.802 & 0.599 & 0.054 & 11.120 \\
\hline KG7 & 0.933 & 0.625 & 0.060 & 10.591 \\
\hline KG8 & 0.840 & 0.546 & 0.086 & 6.277 \\
\hline KG9 & 0.869 & 0.675 & 0.056 & 11.892 \\
\hline
\end{tabular}




\begin{tabular}{|c|c|c|c|c|}
\hline KG10 & 0.829 & 0.633 & 0.056 & 11.292 \\
\hline KG11 & 0.996 & 0.702 & 0.037 & 18.988 \\
\hline KG12 & 0.758 & 0.649 & 0.051 & 12.846 \\
\hline KG13 & 0.717 & 0.509 & 0.082 & 6.265 \\
\hline KG14 & 0.912 & 0.706 & 0.049 & 14.533 \\
\hline KG15 & 0.897 & 0.694 & 0.051 & 13.638 \\
\hline MK1 & 0.825 & 0.516 & 0.076 & 6.940 \\
\hline MK2 & 0.983 & 0.787 & 0.030 & 26.356 \\
\hline MK3 & 0.918 & 0.814 & 0.031 & 26.813 \\
\hline MK4 & 0.816 & 0.712 & 0.053 & 13.419 \\
\hline MK5 & 0.874 & 0.671 & 0.064 & 10.518 \\
\hline MK6 & 0.939 & 0.636 & 0.075 & 8.537 \\
\hline MK7 & 0.893 & 0.583 & 0.071 & 8.369 \\
\hline KS1 & 0.741 & 0.541 & 0.065 & 8.352 \\
\hline KS2 & 0.927 & 0.725 & 0.040 & 17.968 \\
\hline KS3 & 0.998 & 0.794 & 0.031 & 25.792 \\
\hline KS4 & 0.993 & 0.791 & 0.033 & 23.747 \\
\hline KS5 & 0.899 & 0.592 & 0.064 & 9.368 \\
\hline KS6 & 0.885 & 0.683 & 0.053 & 12.831 \\
\hline KS7 & 0.860 & 0.657 & 0.065 & 10.226 \\
\hline KS8 & 0.876 & 0.775 & 0.031 & 24.905 \\
\hline KS9 & 0.721 & 0.513 & 0.071 & 7.333 \\
\hline Th
\end{tabular}

This research was a confirmatory research. Therefore, convergent validity has a provision that the value of loading factor is more than 0.7 (Ghozali, 2014: p.25). Based on the table above, it is explained that all questionnaires of the research variables are valid. This is based on all questionnaire items of research variables namely the teachers' performance, work motivation, and the style of the principal's leadership showing that the value of loading factor is more than 0.7 . It means that the T-Statistics value is $\geq 1.96$.

\section{b. Discriminant Validity}

Discriminant validity explains the ability of each indicator to make a distinction between its constructs and other constructs. If an indicator is incorporated into another construct, the indicator has good discriminant. From the table of cross loading, the overall construct of the constructor is stated to have good discriminant. It means that each construct has the highest relationship with its own variable. There is no greater specific indicator that is not from the same variable (Ghozali, 2014, p.25). Ou tput of discriminant validity from the results of the data processing can be seen in the following table:

Table 2. Discriminant Validity

\begin{tabular}{cccc}
\hline & $\begin{array}{c}\text { The Teachers' } \\
\text { Performance }\end{array}$ & $\begin{array}{c}\text { Work } \\
\text { Motivation }\end{array}$ & $\begin{array}{c}\text { The Style of the } \\
\text { Principal's Leadership }\end{array}$ \\
\hline KG1 & $\mathbf{0 . 7 0 6}$ & 0.295 & 0.380 \\
KG2 & $\mathbf{0 . 7 7 8}$ & 0.341 & 0.393 \\
KG3 & $\mathbf{0 . 8 1 1}$ & 0.576 & 0.534 \\
KG4 & $\mathbf{0 . 8 3 7}$ & 0.479 & 0.597 \\
KG5 & $\mathbf{0 . 8 1 2}$ & 0.458 & 0.448 \\
KG6 & $\mathbf{0 . 8 0 2}$ & 0.397 & 0.563 \\
KG7 & $\mathbf{0 . 9 3 3}$ & 0.330 & 0.386 \\
KG8 & $\mathbf{0 . 8 4 0}$ & 0.507 & 0.307 \\
KG9 & $\mathbf{0 . 8 6 9}$ & 0.536 & 0.422 \\
KG10 & $\mathbf{0 . 8 2 9}$ & 0.595 & 0.325 \\
\hline
\end{tabular}




\begin{tabular}{llll}
\hline KG11 & $\mathbf{0 . 9 9 6}$ & 0.675 & 0.605 \\
KG12 & $\mathbf{0 . 7 5 8}$ & 0.572 & 0.566 \\
KG13 & $\mathbf{0 . 7 1 7}$ & 0.383 & 0.304 \\
KG14 & $\mathbf{0 . 9 1 2}$ & 0.477 & 0.569 \\
KG15 & $\mathbf{0 . 8 9 7}$ & 0.541 & 0.595 \\
MK1 & 0.453 & $\mathbf{0 . 8 2 5}$ & 0.363 \\
MK2 & 0.642 & $\mathbf{0 . 9 8 3}$ & 0.647 \\
MK3 & 0.590 & $\mathbf{0 . 9 1 8}$ & 0.517 \\
MK4 & 0.555 & $\mathbf{0 . 8 1 6}$ & 0.553 \\
MK5 & 0.566 & $\mathbf{0 . 8 7 4}$ & 0.350 \\
MK6 & 0.496 & $\mathbf{0 . 9 3 9}$ & 0.275 \\
MK7 & 0.431 & $\mathbf{0 . 8 9 3}$ & 0.587 \\
KS1 & 0.444 & 0.528 & $\mathbf{0 . 7 4 1}$ \\
KS2 & 0.572 & 0.432 & $\mathbf{0 . 9 2 7}$ \\
KS3 & 0.650 & 0.578 & $\mathbf{0 . 9 9 8}$ \\
KS4 & 0.572 & 0.536 & $\mathbf{0 . 9 9 3}$ \\
KS5 & 0.409 & 0.343 & $\mathbf{0 . 8 9 9}$ \\
KS6 & 0.256 & 0.336 & $\mathbf{0 . 8 8 5}$ \\
KS7 & 0.490 & 0.497 & $\mathbf{0 . 8 6 0}$ \\
KS8 & 0.554 & 0.512 & $\mathbf{0 . 8 7 6}$ \\
KS9 & 0.510 & 0.476 & $\mathbf{0 . 7 2 1}$ \\
\hline
\end{tabular}

Based on the table above, the results of cross loading showed that the latent construct correlation in predicting indicators in each variable was much better than other variable indicators. Thus, the test of discriminant validity has been fulfilled. Then, it can examine the comparison of the root value of AVE and the latent variable correlation coefficient with the correlation betw een constructs.

\section{c. Average Variance Extracted (AVE)}

AVE describes the average variance or extracted discriminant in each indicator so that the ability of each item in dividing measurements with others can be known. AVE value that is equal to or above 0.50 indicates a good convergent.

Table 3. Average Variance Extracted (AVE)

\begin{tabular}{lll}
\hline & AVE & Root of AVE \\
\hline The Teachers' Performance & 0.600 & 0.775 \\
Work Motivation & 0.669 & 0.818 \\
The Style of the Principal's Leadership & 0.669 & 0.818 \\
\hline
\end{tabular}

Based on the table above, the result showed that the root value of AVE w as greater than the AVE value. AVE value of the teachers' performance variable is 0.600 . AVE value of w ork motivation variable is 0.669. AVE value of the style of the principal's leadership variable is 0.669 . At the critical limit of 0.5, the indicators in each construct are valid with the other items in one measurement. It means that discriminant validity has been fulfilled.

\section{d. Composite Reliability}

Composite reliability measures internal consistency and its value must be above 0.6 (Ghozali, 2014, p. 27). The results of composite reliability can be seen in Table 4 .

Table 4. Composite Reliability

\begin{tabular}{lll}
\hline & Cronbach's Alpha & Composite Reliability \\
\hline The Teachers' Performance & 0.891 & 0.907 \\
Work Motivation & 0.807 & 0.858 \\
The Style of the Principal's Leadership & 0.854 & 0.886 \\
\hline
\end{tabular}


Based on the above table, it can be explained that the value of composite reliability is good for the construct of the teachers' performance, work motivation, and the style of the principal's leadership. All of their values are above 0.60 . Thus, it can be concluded that the construct has good reliability.

\section{Inner model analysis}

Assessing the model with PLS is begun by looking at R-Square for each endogenous latent variable as the predictive power of the structural model. The determination coefficient can be seen in the table below.

Table 5. R-Square Value

\begin{tabular}{ll}
\hline & R Square \\
\hline The Style of the Principal's Leadership & \\
Work Motivation & 0.503 \\
The Teachers' Performance & 0.616 \\
\hline
\end{tabular}

The latent variable of the style of the principal's leadership affecting the variable of w ork motivation in the structural model has R2 value of 0.503 that indicates that the model is "Moderate". The latent variables of the style of the principal's leadership and work motivation affecting the variable of the teachers' performance in the structural model have R2 value of 0.616 that indicates that the model is "moderate".

Suitability of the structural model can be seen from Q2, as follows:

$$
\begin{aligned}
\mathrm{Q} 2 & =1-\left[\left(1-R_{1}^{2}\right)\left(1-R_{2}^{2}\right)\right] \\
& =1-[(1-0.253)(1-0.379)] \\
& =1-[(0.747)(0.621)] \\
& =1-[(0.464)] \\
& =0.536
\end{aligned}
$$

The achieved Q2 result is 0.536 . It means that Q2 value above zero provides evidence that the model has

\begin{tabular}{|c|c|c|c|c|c|}
\hline & $\begin{array}{l}\text { Original } \\
\text { Sample }\end{array}$ & $\begin{array}{l}\text { Sample } \\
\text { Mean }\end{array}$ & $\begin{array}{l}\text { Standard } \\
\text { Deviation }\end{array}$ & $\begin{array}{l}\mathrm{T} \\
\text { Statistics }\end{array}$ & $\begin{array}{l}\mathrm{P} \\
\text { Values }\end{array}$ \\
\hline $\begin{array}{l}\text { The Style of the Principal's Leadership -> The } \\
\text { Teachers' Performance }\end{array}$ & 0.557 & 0.574 & 0.042 & 13.128 & 0.000 \\
\hline $\begin{array}{l}\text { The Style of the Principal's Leadership -> } \\
\text { Work Motivation }\end{array}$ & 0.709 & 0.722 & 0.035 & 20.097 & 0.000 \\
\hline $\begin{array}{l}\text { Work Motivation -> The Teachers' } \\
\text { Performance }\end{array}$ & 0.785 & 0.794 & 0.030 & 26.518 & 0.000 \\
\hline $\begin{array}{l}\text { The Style of the Principal's Leadership -> } \\
\text { Work Motivation -> The Teachers' } \\
\text { Performance }\end{array}$ & 0.453 & 0.474 & 0.062 & 8.125 & 0.020 \\
\hline
\end{tabular}
predictive relevance.

\section{Hypothesis Testing}

Hy pothesis testing to answ er the research hy pothesis can be seen in the $t$-statistics in the following table:

Table 6. Betw een Constructs

Based on the table above, it can be explained as follows:

a. The style of the principal's leadership had a positive and significant effect on the teachers' performance. Based on the results of testing the Original Sample value of 0.557 and the T-statistics value of 13.128 which mean greater than 1.96 , the hypothesis stating that the style of the principal's leadership had a positive and significant effect on the teachers' performance can be acceptable.

b. The style of the principal's leadership had a positive and significant effect on work motivation. Based on the results of testing the Original Sample value of 0.709 and the T-statistics value of 20.097 which mean greater than 1.96 , the hypothesis stating that the style of the principal's leadership had a positive and significant effect on work motivation can be acceptable.

c. Work motivation had a positive and significant effect on the teachers' performance. Based on the results of testing the Original Sample value of 0.785 and the T-statistics value of 26.518 which mean 
greater than 1.96 , the hy pothesis stating that w ork motivation had a positive and significant effect on the teachers' performance can be acceptable.

d. The style of the principal's leadership had an indirectly positive and significant effect on the teachers' performance through work motivation. Based on the results of testing the Original Sample value of 0.453 and the T-statistics value of 8.125 which mean greater than 1.96, the hypothesis stating that the style of the principal's leadership had a positive and significant effect on the teachers' performance through work motivation can be acceptable.

\section{RESULT, DISCUSSION, AND SUGGESTIONS}

\section{The Effect of the Style of the Principal's Leadership towards the Teachers' Performance}

Based on the results of the statistical calculation, the original sample value is 0.557 and the T-statistics value is 13.128 which mean greater than 1.96 . The original sample value and the $t$-statistics value showed that the construct of the style of the principal's leadership had a directly positive and significant effect tow ards the construct of the teachers' performance. It means that the better the principal's leadership, the better the teachers' performance will be. On the other hand, the worse the principal's leadership, the low er the teacher's performance will be. The results of this research are in line with the research conducted by Sukardi (2013). The results of Sukardi's research showed that there was a simultaneously positive effect betw een the teachers' professionalism, the principal's leadership, and w ork motivation tow ards the teachers' performance of vocational high schools of business in Semarang.

The results of the research showed that the teachers' professionalism, the principal's leadership, and work motivation been factors affected the teachers' performance were correct. If the principal carries out his leadership role well, the teachers will carry out their duties happily so that the goals of the school can be easily achieved. This is line with the opinion stated by Sulistiyorini (2001). Sulistiyorini stated that a leader in education has to have skills in influencing, motivating, guiding, directing, and moving others. The skills are related with effective and efficient implementation and development of education, teaching, and training to achieve the determined education and teaching goals. There is also a theory stated by Mulyasa (2013). Mulyasa stated that the principal is the driving force, the determinant of the direction of the school policy that will determine how goals of the school and education are generally implemented.

In the future, the principal is expected to become a leader who gets knowledge and skills through learning experiences in theory and practice. The principal also needs to have evaluation steps of every implemented way or style of leadership to anticipate unw anted things by improving his skills specifically in having the strong leader personality, understanding the conditions of the teachers, employees, and students, and communicating in a good way.

\section{The Effect of the Style of the Principal's Leadership towards Work Motivation}

Based on the results of the statistical calculation, the original sample value is 0.709 and the T-statistics value is 20.097 which mean greater than 1.96 . The original sample value and the t-statistics value showed that the construct of the style of the principal's leadership had a positive and significant effect tow ards the construct of work motivation. This showed that the variable of the principal's leadership had a positive and significant effect towards work motivation. If the principal can carry out his duties, functions, and responsibilities properly, effectively, and professionally, his leadership can improve work motivation. It will be more effective if the principal has the strong leader personality, the ability of understanding the conditions of the teachers, employees, and students and communicating in a good way.

The results of this research are in line with the research conducted by AlFahad, Alhajri, and Alqahtani (2013). The results of their research showed that the two styles of the principal's leadership had an effect on the teachers' motivation to get achievement. The two styles had a significantly positive correlation on the teachers' motivation to get achievement. It meant that there was no one style that was claimed to be really better than another. The two styles had to be used properly to improve the motivation of the teachers' performance.

In the future, the principal is expected to be a leader who always maintains balance and suitability in carrying out the leadership function to achieve the goals and in carrying out his duties by understanding the basic characteristics of his subordinates. This is expected that the teachers and all elements at school get attention so that they are motivated to work optimally by having the strong leader personality, 
understanding the conditions of the teachers, employees, and students, and communicating in a good way with the teachers.

\section{The Effect of Work Motivation towards the Teachers' Performance}

Based on the results of the statistical calculation, the original sample value is 0.785 and the T-statistics value is 26.518 which mean greater than 1.96. the original sample value and the $t$-statistics value show ed that the construct of work motivation had a positive and significant effect tow ards the construct of the teachers' performance. It means that the better the work motivation, the better the teachers' performance will be. On the other hand, the worse the work motivation, the lower the teachers' performance will be. The results of this research are in line with the previous research conducted by Suw andi (2012). The results of Suw andi's research showed that motivation of getting achievement had a positive effect towards the teachers' performance. In the future, the teachers are expected to fulfill the demands in education today by being creative in teaching and creating effective and fun teaching methods, implementing new creative teaching patterns, showing motivation in teaching, and getting through adequate preparation. If the teachers have motivation to get achievement and encouragement to be creative in creating innovations in carrying out their teaching duties as well as getting more knowledge through reading, writing and creating, developing themselves through education and training or certain courses, they will improve their performance.

\section{The Effect of the Style of the Principal's Leadership towards the Teachers' Performance through Work Motivation}

Based on the results of the statistical calculation, the original sample value is 0.453 and the T-statistics value is 8.125 which mean greater than 1.96 . The original sample value and the $t$-statistics value showed that the style of the principal's leadership had a positive and significant effect tow ards the teachers' performance through work motivation. The results showed that the principal could carry out his duties, functions, and responsibilities properly and carry out his leadership effectively and professionally so that his leadership could motivate the teachers to get achievement which affected the improvement of the teachers' performance. This was caused by the principal's ability in motivating the teachers to do challenging activities, choose activities with moderate levels of difficulty and avoid easy tasks, work hard, have hopes for success, have the desire to get high grades, discipline and be responsible for their duties, evaluate successes and failures, and find new ways (innovative-creative) in completing their tasks. If the principal has the strong personality, the ability in understanding the conditions of the teachers, employees, and students and communicating in a good way, the teachers' performance will be improved.

The results of this research are in line with opinion stated by Cowley in Wahjosumidjo (2010). Cowley stated that "the leader is one who succeeds in getting others to follow him." It means that a leader functions to move others so that other people consciously want to do what the leader wants. This is also supported by Septiana's (2013) research which shows that principals' leadership and work motivation have a significant and significant effect on teacher performance. The principal is the education leader at school and has a very big role in advancing education at school. The quality of the principal's leadership determines work motivation, synergistic collaboration between all elements at school, interest in the development and progress of education, the conducive work environment, the development of the quality of the teachers' professionalism, and the improvement of the quality of the graduates. In carrying out his duties, the principal has to be able to understand the basic characteristics of his subordinates to ens ure that the teachers and all elements at school get attention so that they can get motivated to work optimally.

\section{Conclusion}

Based on the analysis and discussion above, it can be concluded as follows:

1. The leadership style of the principal has a positive and significant direct effect on teacher performance of 0.557 and a statistical $\mathrm{T}$ value of $13.128 \geq 1.96$. This shows that the better the leadership of the principal, the better the performance of the teacher.

2. The principal's leadership style has a positive and significant influence on w ork motivation of 0.709 and a statistical $T$ value of $20,097 \geq 1.96$. This means that the better the headmaster's leadership, the higher his work motivation. 
3. Work motivation has a positive and significant effect on teacher performance of 0.785 and a statistical $\mathrm{T}$ value of $26.518 \geq 1.96$. This means that the higher the work motivation, the higher the performance of the teacher.

4. The principal's leadership style has a positive and significant influence on teacher performance through work motivation of 0.453 and a statistical $\mathrm{T}$ value of $8.125 \geq 1.96$. This means that the principal's role in teacher work motivation has an effect on teacher performance.

\section{REFERENCES}

AlFahad, H,. AlHajri, S,. \& Alqahtani, A. (2013). The relationship between school principals' leadership styleand teachers' achievement motivation. Proceedings of 3rd Asia-Pacific Business Research Conference 25 - 26 February, Kuala Lumpur, Malaysia, ISBN: 978-1-922069-19-1

Arikunto, S. (2010). Prosedur Penelitian Suatu Pendekatan Praktik. Jakarta: Rineka Cipta.

Demir, K. (2008). Transformational leadership and collective effiacy: the moderating roles of collaborative culture and teachers' self-effiacy. Egitim Arastirmalari-Eurasian Journal of Educational Research. 8(33), 93-112.

Firmawati, Yusrizal, \& Usman, N. (2017). Pengaruh Kepemimpinan Kepala Sekolah dan Motivasi Kerja terhadap Kinerja Guru. Jurnal Magister Administrasi Pendidikan. 5(3). 167-171.

Ghozali, I. (2014). Structural equation modeling, metode alternatif dengan partial least square (PLS). Edisi 4. Semarang: Badan Penerbit Universitas Diponegoro.

Haryono, S. (2017). Metode SEM untuk Penelitian Manajemen AMOS LISREL PLS. Luxima Metro Media.

Mulyasa, E. (2013). Menjadi Kepala sekolah Profesional Dalam Konteks Menyukseskan MBS \& KBK. Bandung: PT. Remaja Rosdakarya.

Septiana, R. (2013). Pengaruh Kepemimpinan Kepala Sekolah dan Motivasi Kerja terhadap Kinerja Guru SMP Negeri Wonosari. Jurnal Penelitian Pendidikan, 2 (1), 107-118.

Sugiyono (2010). Metode Penelitian Pendidikan Pendekatan Kuantitatif, Kualitatif, dan RED. Bandung: Alfabeta.

Sukardi (2013). Pengaruh Profesionalisme Guru, Kepemimpinan Kepala Sekolah dan Motivasi Kerja Terhadap Kinerja Guru SMK (Bisnis) se-kota Semarang.

Sulistyorini (2001). Hubungan Antara Manajerial Kepala Sekolah Dan Iklim Organisasi Dengan Kinerja Guru. Jurnal IlmumPendidikan.

Supriadi, E., \& Yusof, H. A. R. B. M. (2015). Relationship between instructional leadership of headmaster and work discipline and work motivation and academic achievement in primary school at special areas of Central Jakarta. Journal of Education and Learning, 4(3).

Suw andi, P. (2012). Peran Supervisi Pengaw as Sekolah Memoderasi Pengaruh Disiplin Kerja dan Motivasi Berprestasi Kerja Terhadap Kinerja Guru (Studi Pada Guru Sekolah Dasar se-Kecamatan Limpung). Student's Journal of Economic and Management. 1(1).

Vivianti. \& Hadi, S. (2015). Peran Kepala Smk Negeri Di Kota Yogyakarta Berdasarkan Persepsi Guru. Jurnal Pendidikan Vokasi. 5(3). 394-404.

Wahab, J. A., Fuad, C. F. M., Ismail, H., \& Majid, S. (2014). Headmasters' transformational leadership and their relationship with teachers' job satisfaction and teachers' commitments. International Education Studies, 7(13), 40-48.

Wahjosumidjo (2010). Kepemimpinan Kepala Sekolah Tinjauan Teoritik dan Permasalahannya. Jaka rta: PT. Raja Grafindo Persada.

Wahlstrom, L. K., \& Louis, S. K. (2008). How teachers experience principals leadership: The roles of professional community, trust, effiacy, and shared responsibility. Educational Administration Quarterly, 44(4), 458-495.

Yamin, S. \& Kurniawan, H. (2009). Structural Equation Modeling. Jakarta: Salemba Infotek.

Yieng, W. A., \& Daud, K. B. (2017). Technology Leadership in Malaysia â€ $€^{\mathrm{TM}}$ s High Performance, 4(1), 8-14. 